\title{
Oxidative stability of crude palm oil after deep frying akara (Fried Bean Paste)
}

\author{
Deusdélia Teixeira de ALMEIDA ${ }^{1}$, Fabiana Martins CURVELO $^{1}$, Mariana Melo COSTA ${ }^{1}$, Thaís Vieira VIANA ${ }^{1 *}$, \\ Patricia Condé de LIMA ${ }^{1}$
}

\begin{abstract}
For this study 47 samples of crude palm oil (CPO) were collected, consisted of what had been used for 4 hours around the city of Salvador-Bahia. To evaluate the quality of CPO were analyzed: Total Polar Compound (TPC; \%) by Adsorption Chromatography (AC), Testo 270 and Fricheck; Free fatty acids (FFA; \% oleic acid), Color (CIELab); Total Carotenoids (TC; ppm), induction time (IT, h) and fatty acids composition (g $100 \mathrm{~g}$-1). The TPC analysis by Testo 270 and Fricheck showed a poor linear correlation with AC (0.69 and 0.60 respectively). Otherwise $44.70 \%$ and $36.95 \%$ of samples were completely oxidized, according to CA and IT methods. All samples presented TC (11.01-331.45 ppm) and yellow color predominance. Trans fatty acids, C18:1t in $17.02 \%$ and $\mathrm{C} 18: 3 \mathrm{t}$ in $65.65 \%$ of the samples were identified. The results demonstrate the need in the deep frying control, respect to techniques used during process. As well the improvement of the quality of palm oil fresh, can minimize the degradation process during th deep frying.
\end{abstract}

Keywords: akara; crude palm oil; deep frying; oxidative fatty.

Practical Application: The study has an influence in practice of the deep-frying, food preparation commonly used, in addition to discuss the most important criteria to get quality-fried products. Palm oil is widely used for deep-frying foods due to its high availability and considering the cultural and public health importance of consuming.

\section{Introduction}

The deep frying is a complex culinary method, which is influenced by a significant number of intrinsic and extrinsic variables: quantity of water in the food, oxygen and high temperatures are some of the intrinsic variables. The extrinsic variables could be related to the oil/shortening composition, types of material and heating applied in the processes, or the relation between equipment surface and volume of oil.

The oil used in the deep-frying process is one of the most important criteria to get quality-fried products (Corsini et al., 2008). In this regard, the refined palm oil is widely used for deep-frying foods due to its high availability in the market, competitive prices, and a pleasant odor compared to other vegetable oils (Edem, 2002; Gee, 2007; Koushki et al., 2015).

However, as others vegetable oils without a control in the deep frying process, occur an increment in hydrolytic and oxidative reactions that produces total polar compounds (TPC), free fatty acids (FFA) and others toxic substances to human health (O’Donnell, 1995; Silva \& Pereira, 2008).

Crude palm oil (CPO) is consumed only in Brazil and Africa (Lody, 2009) and one of its main uses in Brazilian cuisine, specifically in Bahia, is fried akara. It is made with decorticated cowpea bean (Vigna unguiculata), onion and salt, and deep fried in CPO (Corrêa et al., 2003; Instituto do Patrimônio Histórico e Artístico Nacional, 2005). Such food is sold on the streets by "Baianas de Acarajé" (Instituto do Patrimônio Histórico e Artístico Nacional, 2005).
Whereas research related to $\mathrm{CPO}$ and frying focus on controlled laboratory tests, under conditions that are different from practical reality, and considering the cultural and public health importance of consuming the akara as street food, this proposal aims to evaluate oxidative stability of crude palm oil after deep frying akara.

\section{Materials and methods}

\subsection{Study site and sampling}

There are approximately 1,385 akara points of sale recorded at the Association of Baianas of Acarajé and Porridge (ABAM) throughout the city of Salvador, Bahia, Brazil. In other study 149 (11\%) of those were selected. The selection of the sample was divided in proportions between the sales points and the twelve regions of Salvador City. Dividing the total of sales points through the population of Baianas of Acarajé and multiplying by the intended size of the sample (Curvelo et al., 2011). Crude palm oil samples collected at each point of sale consisted of what had been used for four hours (usual selling time at points). After collection, the samples were transported to the laboratory in thermal containers, homogenized and stored in $100 \mathrm{~mL}$ amber glass bottles at $-18^{\circ} \mathrm{C}$ until analysis.

For the present study 47 samples were selected, whose acidity was $\geq 5 \%$ in oleic acid (Codex Alimentarius, 2013). 


\subsection{Analytical determination}

Free fatty acids (FFA \%)

Fatty acids was analyzed in triplicate according to AOCS Ca 5a-40 (American Oil Chemists' Society, 2003).

\section{Fatty acid methyl esters (FAME)}

Fatty acids were transformed to their methyl esters following the method of Institute Adolfo Lutz (IAL, 2005) and were determined with a Shimadzu, Model 17A gas chromatograph (Shimadzu, Japan) equipped with a flame ionization detector (FID), split/splitless injector, and CP-Sil 88 capillary column (100 $\mathrm{m} \times 0.25$ i.d., $0.25 \mu \mathrm{m}$ film thickness) (CP 7420 Varian, EUA). The operation parameters were as follows: column temperature held at $45^{\circ} \mathrm{C}$ for $2 \mathrm{~min}$, then increased at $20^{\circ} \mathrm{C}$ min to $165^{\circ} \mathrm{C}$ and held at this temperature for $15 \mathrm{~min}$, and then increased at $4{ }^{\circ} \mathrm{C} \mathrm{min}-1$ until $220^{\circ} \mathrm{C}$ (35 min). The injector and detector were kept at $250^{\circ} \mathrm{C}$. The gas flow rates used were $1 \mathrm{~mL}$ min -carrier gas (He), $30 \mathrm{~mL} \mathrm{~min}^{-1}$ for $\mathrm{H}_{2}$ and $300 \mathrm{~mL} \mathrm{~min}^{-1}$ for synthetic air. The sample split mode was $1 / 40$. The injections were performed in duplicate, and the double injection volume was $1 \mu \mathrm{L}$. For the fatty acid identification, the retention times were compared to those of standard methyl esters (Sigma, St. Louis, MO, USA). For quantification (in $\mathrm{g}$ fatty acid $100 \mathrm{~g}^{-1}$ of total lipids), tricosanoic acid methyl ester from Sigma (USA) was used as an internal standard (23:0) at $2.5 \mathrm{mg} \mathrm{mL}^{-1}$ in n-hexane. Theoretical FID correction factor (Visentainer \& Franco, 2012) values were used to obtain the concentration values. Fatty acid contents were reported in $g$ per $100 \mathrm{~g}$ of total lipids with the following Equation (1): $\mathrm{FA}=\mathrm{AX}^{\star} \mathrm{WIS}^{\star} \mathrm{CFx} / \mathrm{AIS}^{\star} \mathrm{Wx}^{\star} \mathrm{CFAE}$ where FA is $\mathrm{g}$ of fatty acids per $100 \mathrm{~g}$ of total lipids, AX is the peak area (fatty acid methyl esters), AIS is the peak area of the internal standard (IS) (tricosanoic acid methyl ester (23:0)), WIS is the IS weight (g) added to the sample (in g), WX is the sample weight (in g), CFX is the theoretical correction and CFAE is the conversion factor necessary to express the results as $g$ of fatty acids rather than as methyl esters.

\section{Rancimat stability test}

The oxidative stability of the oil samples was determined with a Rancimat 743 (Metrohm AG, Switzerland). In brief, $3 \mathrm{~g}$ of the vegetable oil were weighed into the reaction vessel and heated at $120^{\circ} \mathrm{C}$ with an air flow of $10 \mathrm{~L} \mathrm{~h}^{-1}$. The volatile products released during the oxidation process were collected in a flask containing distilled water. The oxidation process was recorded automatically by measuring the change in conductivity of the distilled water due to the formation of volatile compounds and the oil stability index (OSI), which is expressed in hours (h) (Läubli \& Bruttel, 1986). At each time point, eight oil samples were analyzed simultaneously by the equipment. Each sample was analyzed in duplicate.

\section{Colors measurement of crude palm oil}

Colors was measured using quartz cells of $2 \mathrm{~mm}$ thick in Chroma Meter CR-400 (Konica Minolta Sensing Inc., Japan) and expressed in terms of lightness $\left(\mathrm{L}^{*}\right)$, red-green characteristics $\left(a^{\star}\right)$, blue-yellow characteristics $\left(b^{*}\right)$, Hue angle $\left(h^{\circ}\right)$ and chroma
$\left(C^{\star}\right) ; h^{\circ}=\tan -1\left(b^{\star} / a^{\star}\right)$ and $C^{\star}=\left[\left(a^{\star} 2+b^{\star} 2\right) 1 / 2\right]$. Each color value reported was the mean of three determinations at $22-24^{\circ} \mathrm{C}$ (Colorimetric Committee).

\section{Total carotenoids}

Crude palm oil samples $( \pm 0.2-0.3 \mathrm{~g})$ were dissolved in petroleum ether and quantified in a Lambda $25 \mathrm{UV}-\mathrm{Vis}$ spectrophotometer (Perkin Elmer, Singapore) at $450 \mathrm{~nm}$ with an absorption coefficient (A1\%1cm) of 2592 (Rodriguez-Amaya \& Kimura, 2004). The analysis was performed in triplicate.

\section{Total polar compound (TPC)}

Total polar compound (TPC) content was determined gravimetrically according to a mini column method described previously, with slight modification (Dobarganes et al., 2000). In brief, approximately $0.5 \mathrm{~g}$ of crude palm oil was dissolved in the elution solvent and introduced into a glass column filled with silica gel slurry and elution solvent. This elution solvent was a mixture of light petroleum (b.p. $40-60^{\circ} \mathrm{C}$ ) and diethyl ether 94:6 (v:v). A chromatographic glass column with an internal diameter of $1 \mathrm{~mm}$ and a length of $15 \mathrm{~mm}$, containing $5 \mathrm{~g}$ of silica gel (with a particle size $0.063-0.200 \mathrm{~mm}$ and 70-230 mesh) adjusted to a water content of $5 \%$ was used. Non-polar compounds were eluted with $60 \mathrm{~mL}$ of elution solvent and polar compounds fraction was eluted with $50 \mathrm{~mL}$ diethyl ether. A dropping funnel was used and flow rate was adjusted to approximately $1.5 \mathrm{~mL} / \mathrm{min}$. Solvent was removed by rotary evaporation and the flask was flushed with a stream of nitrogen to ensure dryness. The completeness of fractionation was evaluated by analytical thin-layer chromatography (TLC) with an elution system of petroleum ether:diethyl ether:acetic acid (70:40:1; v:v:v).

\section{Statistical analysis}

Statistical analyses were carried out with SPSS 13.0.1 for Windows. Regression analysis was performed to evaluate the relationships between the chemical and physical degradation parameters. The model fitting was judged by coefficient of determination $\left(\mathrm{R}^{2}\right)$, which represents the proportion of variability that has been accounted for by the regression equation. Linear correlation between two parameters was assessed by Sperman's correlation (r).

\section{Results and discussion}

\subsection{Free fatty acids (FFA \%)}

A high fraction of free fatty acids in crude palm oil is an indication of the impairment of oil quality (Almeida et al., 2013). In this study, the acidity in oleic acid, ranged from $4.88-8.77 \%$, consistent with a study about crude palm oil fresh (Almeida et al., 2013). Importantly, there are no official parameters established for disposal of crude vegetable oil used in frying, such as palm oil, although acidity limits exist to discard refined oils (Tarmizi \& Lin, 2008). The raw material of crude palm oil is already quite FFA \%, about $10 \mathrm{mg} \mathrm{KOH} / \mathrm{g}$ according to the CODEX 210 (Codex Alimentarius, 2013) and Brazilian legislation (Brasil, 2005), which makes this not a good parameter to determine the disposal of oil used in akara frying. 


\subsection{TPC content using the conventional and quick methods}

\section{Conventional methods}

Measurement of polar components is recognized as one of the most accurate assessments of the thermo-oxidative degradation of frying oils, since the measured components are non-volatile and are representative of the major reactions occurring during frying (Dobarganes et al., 2000). The TPC include hydrolysis products (polymerized triacylglycerols, oxidized triacylglycerols, diacylglycerols and free fatty acids) (Dobarganes et al., 2000).

The TPC contents of the samples obtained using the conventional method, presented values from $14.92 \pm 0.17 \%$ to $35.63 \pm 1.47 \%$, distributed as shown in Table 1 . The amounts of TPC in $44.70 \%$ of the oils were above the regulatory $25 \%$ discard point (Codex Alimentarius, 2013). Studies conducted by Almeida et al. (2013), found for fresh CPO, TPC values between 13.61-18.65\%, more than half of what was predicted for vegetable oils discard (4.0-7.5\%).

Matthäus (2007), also reported a higher TPC for palm olein, attributed to the higher TPC value in the fresh palm olein. However it cannot be claimed that all these oils were in discard point, since the higher amounts of total polar compounds in palm oils are mainly due to a higher level of diacylglycerol contents (4.0-7.5\%) compared to other vegetable oils.

\section{Testo 270}

The CPO fried showed TPC values ranging from $5.5 \pm 0.00 \%$ to $23.75 \pm 0.40 \%$ when evaluated by the Testo 270 . A linear relation between the results of Testo and conventional methods was obtained. The equation that represented the model was TPC $\%($ Testo 270$)=-1.8229+0.5709^{*}$ conventional method and the value found for the coefficient of correlation (r) was 0.69 , explaining only $47.3 \%$ of the variation in the results of this quick test, which is considered insufficient. These results differ from those found by Osawa et al. (2012), who showed a correlation coefficient of $r=0.90$ and $R^{2}$ of $80.5 \%$ from the Test 265 and the official methodology in 59 samples of palm olein and cotton oil in discarded frying oil. According to Bansal et al. (2010), there are some disadvantages in the use of Testo 270, which included the presence of water, salt, minerals, long warm up time and the need of daily calibration factors that affect the polarity of a sample and can give false information on the TPC. Nevertheless, in these methods, there are problems in determining the actual level of oil degradation as it depends on the food-oil combination used and is severely affected by the food moisture retained by the frying oil (Bansal et al., 2010; Weisshaar, 2014). In the specific case of the CPO, the presence of largest content of water, impurities minerals may to be responsible for the results obtained, since the other cited studies analyzed refined oils Akusu et al. (2000), Szydłowska-Czerniak et al. (2013).

\section{Fri-check}

The TPC results obtained using the Fri-check showed a poorly linear correlate with the results obtained using the conventional method. It has been reported that the test is imprecise and provides results that correlate poorly with total polar compounds (Osawa et al., 2012). According that same author, the kind of oil /fat used or the type of food fried could indeed have had some influence, since the same kind of oils were dispersed and did not follow a linear pattern. In our study was noticed that many akara particles were released in the oil (Curvelo et al., 2011), so even with filtration, some of those particles could remain. Moreover the samples presented olein and stearin in variable amounts, whose spontaneously separate in the packages. It consists though of a mixture of low melting and high melting glycerides which form a heterogeneous slurry in the liquid oil (Kumar \& Krishna, 2014). Those factors could interfering in the shown results.

\section{Changes in oxidative stability}

The oxidative stability of oils, measured as the induction period determined using the Rancimat method shown in Table 1. Clearly distinct results were observed for all of the samples (0.08-15.97 h). Anwar et al. (2003) analyzed various vegetable oils and fats and concluded that palm oil and vaspanati had a longer induction period than other fats and oils. Studies conducted by

Table 1. Ranges of total polar compounds (TPC), induction time (TI), total carotenoids (CT) and free fatty acids (FFA) in samples of crude palm oil after deep frying akara.

\begin{tabular}{|c|c|c|c|c|c|c|c|c|c|c|c|c|c|}
\hline \multicolumn{2}{|c|}{ Districts } & \multicolumn{2}{|c|}{ TPC (\%) } & \multicolumn{2}{|c|}{ Fricheck (\%) } & \multicolumn{2}{|c|}{ Testo 270 (\%) } & \multicolumn{2}{|c|}{ TI (h) } & \multicolumn{2}{|c|}{ CT (ppm) } & \multicolumn{2}{|c|}{ FFA (\%) } \\
\hline & $\mathbf{N}$ & Means & $\begin{array}{l}\text { Standard } \\
\text { deviation }\end{array}$ & Means & $\begin{array}{l}\text { Standard } \\
\text { deviation }\end{array}$ & Means & $\begin{array}{l}\text { Standard } \\
\text { deviation }\end{array}$ & Means & $\begin{array}{l}\text { Standard } \\
\text { deviation }\end{array}$ & Means & $\begin{array}{l}\text { Standard } \\
\text { deviation }\end{array}$ & Means & $\begin{array}{l}\text { Standard } \\
\text { deviation }\end{array}$ \\
\hline 1 & 11 & 23.64 & 5.85 & 8.79 & 5.66 & 15.34 & 5.96 & 3.32 & 4.14 & 59.74 & 51.11 & 17.72 & 3.53 \\
\hline 2 & 6 & 20.93 & 2.74 & 7.40 & 1.73 & 11.15 & 4.36 & 1.70 & 1.02 & 111.02 & 120.47 & 17.34 & 1.46 \\
\hline 3 & 2 & 21.85 & 1.13 & 6.08 & 0.53 & 9.13 & 0.88 & 5.62 & 6.23 & 106.21 & 39.41 & 16.20 & 0.37 \\
\hline 4 & 2 & 23.57 & 11.32 & 11.18 & 5.48 & 16.38 & 6.19 & 0.85 & 0.00 & 24.13 & 7.22 & 17.02 & 1.32 \\
\hline 5 & 3 & 20.18 & 3.88 & 5.40 & 2.17 & 9.83 & 2.79 & 8.97 & 0.00 & 171.50 & 129.53 & 17.24 & 1.58 \\
\hline 6 & 8 & 22.82 & 4.79 & 7.33 & 1.86 & 13.13 & 2.13 & 3.07 & 3.79 & 42.14 & 39.38 & 19.69 & 2.69 \\
\hline 7 & 6 & 19.22 & 3.80 & 6.03 & 0.56 & 9.92 & 1.72 & 1.83 & 2.46 & 43.69 & 23.11 & 21.15 & 1.17 \\
\hline 8 & 9 & 20.24 & 2.47 & 7.00 & 1.74 & 10.97 & 2.80 & 7.46 & 5.20 & 98.54 & 64.87 & 21.35 & 5.31 \\
\hline 9 & 1 & 22.58 & 0.00 & 10.10 & 0.00 & 15.00 & 0.00 & 0.99 & 0.00 & 14.54 & 0.00 & 22.65 & 0.00 \\
\hline 10 & 1 & 13.82 & 0.00 & 5.05 & 0.00 & 9.00 & 0.00 & 11.04 & 0.00 & 244.85 & 0.00 & 18.49 & 0.00 \\
\hline
\end{tabular}

Data are presented as means (standard deviation). $\mathrm{N}=$ number of samples. 
Almeida et al. (2013) demonstrated IT ranging for fresh crude palm oil (CPO) produced in Bahia and for oils produced in Pará, Brazil. Both oils are used to fried akara but, as the one produced in Bahia has low quality, the "Baianas de Acarajés", usually mix it with those obtained in Pará, which could explain, in part, the variation in IT observed. Also to be considered is that the process of deep frying akara is discontinued, often done in open areas, using enameled pots with large diameter without any temperature control, factors that tend to accelerate the oxidative processes. Coupled with the practice of the "Baianas de acarajés" of replace the volume of the frying oil with both new and reused oil (Weisshaar, 2014) that can also affect this variability, which means that $36.95 \%$ of the samples have been completely oxidized (Table 1).

\section{Total carotenoids}

The carotenes are responsible for the rich orange-red color of CPO and it contains $33 \% \alpha$-carotene, $65 \% \beta$-carotene and $2 \%$ other carotenoids such as $\gamma$-carotene and lycopene (Ng et al., 2012). The Codex Alimentarius (2013) establishes values for the total carotenoids of 500-2000 ppm. Carotenoids stability over time depends on a number of factors such as temperature, $\mathbf{O}_{2}$ availability, and light transmission of the packing material (Trigueiro \& Penteado, 1993; RodriguezAmaya, 1996).

Zeb \& Murkovic (2011), characterized the effects of $\beta$-carotene oxidation in triacylglycerol and concluded that half of $\beta$-carotene content degrades during the first three hours of heat treatment. Ndjouenkeu \& Ngassoum (2002), studying vegetable oils in frying, observed that heating can lead to bleaching, as in the case of palm oil, due to the destruction of carotenoids which are responsible for its color. Considering these prerogatives, an absence of carotenoids would be expected in this study, since the CPO were used for over four hours of frying; however, the levels of this molecules ranged from 11.01 to $331.45 \mathrm{ppm}$ which could be achieved by the turnover, as mentioned above.
Cor

Table 2 shows the average values of the color coordinates in CIELab space of the analyzed oils. These coordinates are the corresponding quadrant with positive values for $\mathrm{a}^{*}, \mathrm{~b}$ * and $L^{*}$, with a predominance of yellow pigment shown by the high values of $b^{*}$ and average $h_{a b}$ of $85.12^{\circ}$. Rossi et al. (2001) reported the $L^{*} a^{*} b^{*}$ value of Indonesian crude palm oil as $39.03,47.35$ and 67.26 , respectively. Comparing these results with the contents of the frying oils (Table 2), there is the loss of red color $\left(\mathrm{a}^{*}=2.21-13.0\right)$, and higher values of $\mathrm{L}^{*}$ (59.11 - 67.88), $\mathrm{b}^{\star}$ (56.87-74.50), $\mathrm{C}^{\star}(57.20-73.94)$ and $\mathrm{h}_{\mathrm{ab}}$ $\left(79.53-88.21^{\circ}\right)$, changes that can be attributed to the exponential degradation of carotenoids throughout the heating or influenced by trace pigments and tocopherols and tocotrienols which are particularly prone to formation of red-brown quinone polymers (Aladedunye \& Przybylski, 2009).

For changes in the coloration of the oils studied, an inverse correlation of these molecules was observed with $L^{*}(r=-0.439, p<0.02)$ $\mathrm{h}_{\mathrm{ab}}=(\mathrm{r}=-0.743, \mathrm{p}<0.00)$ and positive with $\mathrm{a}^{\star}(0.811 ; \mathrm{p}<0.00)$ and $b^{*}(r=0.607 ; p<0.00)$. Moreover an inverse correlation of carotenoids was observed with TPC $(r=-0447$; $p<0.00)$, demonstrating the effect of oxidation on the loss of such molecules.

\section{Fatty acids composition}

The crude palm oil can be considered balanced oil in terms of fatty acids, since it contains almost equal amounts of saturated and unsaturated fatty acids (Table 3) (Tan \& Man, 2000). According to the CODEX 210 (Codex Alimentarius, 2013), are identified in fresh CPO fatty acids shown in Table 3, in addition to C20:1 (nd-0.4) e C:22 (nd-0.2). In this study the major saturated fatty acids observed in the frying oils were palmitic (35.44-46.45 $\left.\mathrm{g} 00 \mathrm{~g}^{-1}\right)$

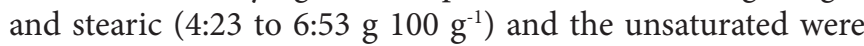

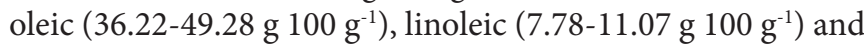

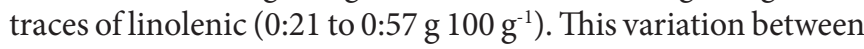
the values of fatty acids can either be due to the frying process, as well as the way that the palm oil is manufactured and sold. It should also be considered that the olein has relatively more

Table 2. Color coordinates (CIELab) in crude palm oil after deep frying akara.

\begin{tabular}{|c|c|c|c|c|c|c|c|c|c|c|c|}
\hline \multirow[b]{2}{*}{ Districts } & \multirow[b]{2}{*}{$\mathbf{N}$} & \multicolumn{2}{|c|}{$L^{*}$} & \multicolumn{2}{|c|}{$a^{\star}$} & \multicolumn{2}{|c|}{$\mathbf{b}^{*}$} & \multicolumn{2}{|c|}{$\mathrm{C}^{*}$} & \multicolumn{2}{|c|}{$\mathbf{h}_{\mathrm{ab}}$} \\
\hline & & Means & $\begin{array}{l}\text { Standard } \\
\text { deviation }\end{array}$ & Means & $\begin{array}{l}\text { Standard } \\
\text { deviation }\end{array}$ & Means & $\begin{array}{l}\text { Standard } \\
\text { deviation }\end{array}$ & Means & $\begin{array}{l}\text { Standard } \\
\text { deviation }\end{array}$ & Means & $\begin{array}{l}\text { Standard } \\
\text { Deviation }\end{array}$ \\
\hline 1 & 11 & 62.18 & 9.85 & 5.09 & 7.99 & 63.77 & 13.34 & 63.88 & 12.25 & 85.06 & 7.79 \\
\hline 2 & 6 & 65.70 & 3.79 & 5.98 & 8.03 & 71.42 & 10.97 & 72.04 & 11.27 & 85.54 & 5.91 \\
\hline 3 & 2 & 53.04 & 9.10 & 9.89 & 4.63 & 59.83 & 15.96 & 60.68 & 16.39 & 80.96 & 2.72 \\
\hline 4 & 2 & 57.27 & 12.45 & 3.80 & 1.39 & 54.87 & 9.09 & 54.86 & 8.96 & 86.16 & 0.74 \\
\hline 5 & 3 & 65.63 & 8.56 & 10.59 & 8.12 & 68.90 & 8.07 & 69.90 & 8.66 & 81.60 & 6.43 \\
\hline 6 & 8 & 61.81 & 7.54 & 5.22 & 6.23 & 62.50 & 11.44 & 62.86 & 11.51 & 85.72 & 4.42 \\
\hline 7 & 6 & 62.20 & 11.41 & 0.85 & 6.64 & 64.07 & 19.18 & 64.38 & 19.13 & 86.62 & 5.88 \\
\hline 8 & 9 & 65.15 & 5.16 & 6.71 & 6.90 & 71.79 & 13.17 & 72.04 & 12.85 & 85.30 & 6.10 \\
\hline 9 & 1 & 70.18 & 0.00 & -2.61 & 0.00 & 52.34 & 0.00 & 52.42 & 0.00 & 92.86 & 0.00 \\
\hline 10 & 1 & 59.68 & 0.00 & 15.88 & 0.00 & 72.69 & 0.00 & 74.41 & 0.00 & 77.68 & 0.00 \\
\hline
\end{tabular}

Data are presented as means (standard deviation). $\mathrm{N}=$ number of samples. $\mathrm{L}^{*}$ (lightness); $\mathrm{a}^{\star}$ (negative values indicate green and positive values indicate red, $\left.-\mathrm{a} /+\mathrm{a}\right) ; \mathrm{b}^{*}$ (negative values indicate blue and positive values indicate yellow, $+\mathrm{b} /-\mathrm{b}) ; \mathrm{C}^{\star}$ (choma) and $\mathrm{h}_{\mathrm{ab}}$ (hue angle). 


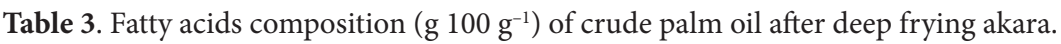

\begin{tabular}{|c|c|c|c|c|c|c|}
\hline $\begin{array}{c}\text { FAME } \\
\left(\mathrm{g}_{\left.100 \mathrm{~g}^{-1}\right)}\right.\end{array}$ & $\mathbf{N}$ & Mínimum & Maximum & Means & $\begin{array}{l}\text { Standard } \\
\text { deviation }\end{array}$ & $\begin{array}{l}\text { CODEX } 210 \text { Codex } \\
\text { Alimentarius, 2013) }\end{array}$ \\
\hline C14:0 & 47 & 0.64 & 1.00 & 0.81 & 0.01 & $0.5-2.0$ \\
\hline C16:1 & 14 & 0.12 & 0.18 & 0.14 & 0.01 & nd- 0.6 \\
\hline C17:0 & 12 & 0.09 & 0.16 & 0.13 & 0.01 & nd- 0.2 \\
\hline C18:1n9 & 47 & 36.22 & 49.28 & 42.35 & 0.33 & $36.0-44.0$ \\
\hline $\mathrm{C} 18 \mathrm{a} 2 \mathrm{c}$ & 47 & 7.78 & 11.07 & 9.53 & 0.11 & $9.0-12.0$ \\
\hline C20:0 & 47 & 0.33 & 0.88 & 0.42 & 0.01 & nd- 1.0 \\
\hline $\mathrm{C} 18: 3 \mathrm{t}$ & 31 & 0.13 & 0.25 & 0.16 & 0.00 & - \\
\hline C18:3 C & 47 & 0.21 & 0.57 & 0.28 & 0.01 & nd- 0.5 \\
\hline
\end{tabular}

$\mathrm{SFA}=$ saturated fatty acids $=$ MUFA = monounsaturated fatty acids; $\mathrm{PUFA}=$ polyunsaturated fatty acids. $\mathrm{N}=$ sample number. $\mathrm{Nd}=$ not detected.

oleic and linoleic acids and less palmitic acid than palm stearin (Matthäus, 2007).

Importantly highlight the presence of trans fatty acids $\mathrm{C} 18: 1 \mathrm{t}$ and $\mathrm{C} 18: 3 \mathrm{t}$, in $17.02 \%$ and $65.95 \%$ of the samples respectively, was observed. In a study of Almeida et al. (2013) with fresh $\mathrm{CPO}$ was detected in the presence of $\mathrm{C} 18: 3 \mathrm{t}$ in $50 \%$ of samples $(0: 12$ to $0: 34 \mathrm{~g} / 100 \mathrm{~g})$. These results are similar to those obtained in this study, when increased production of C18:3t was found, probably due to the higher degree of oxidation of linoleic to oleic acid.

\section{Conclusions}

Accordingly, to the determination of $\mathrm{CPO}$ official methodology $44.70 \%$ of oils showed TPC above the maximum allowed value (25\%). Furthermore, the analysis by Fricheck and Testo 270, fast tests, are not suitable to evaluate TPC values presenting results which correlate poorly with the official methodology. The induction time results showed that $36.95 \%$ of the samples were completely oxidized. All samples contained wide carotenoids variation, and the color had had a predominance of yellow pigment, with losses of red color and brightness increased. Importantly highlight the presence of trans fatty acids, C18:1t and C18:3t of the samples. The results demonstrate the need in the deep frying control, respect to techniques used during process. As well the improvement of the quality of palm oil fresh, can minimize the degradation process during the deep frying.

\section{References}

Akusu, M. O., Achinewhu, S. C., \& Mitchell, J. (2000). Quality attributes and storage stability of locally and mechanically extracted crude palm oils in selected communities in Rivers and Bayelsa States, Nigeria. Plant Foods for Human Nutrition, 55(2), 119-126. PMid:10898481. http://dx.doi.org/10.1023/A:1008197612350.
Aladedunye, F. A., \& Przybylski, R. (2009). Degradation and nutritional quality changes of oil during frying. Journal of the American Oil Chemists'Society, 6(2), 149-156. http://dx.doi.org/10.1007/s11746008-1328-5.

Almeida, D. T., Nunes, I. L., Conde, P. L., Rosa, R. P. S., Rogèrio, W. F., \& Machado, E. R. (2013). A quality assessment of crude palm oil marketed in Bahia, Brazil. Grasas y Aceites, 64(4), 387-394. http:// dx.doi.org/10.3989/gya.118412.

American Oil Chemists' Society - AOCS. (2003). Official methods of recommended practices of the American Oil Chemists' Society, Methods Ca 5a-40, AOCS, Cd 8b-90 (5th ed.). Champaign: AOCS Press.

Anwar, F., Bhanger, M. I., \& Kazib, T. G. (2003). Relationship between Rancimat and active oxygen method values at varying temperatures for several oils and fats. Journal of the American Oil Chemists' Society, 80(2), 151-155. http://dx.doi.org/10.1007/s11746-003-0668-2.

Bansal, G., Zhou, W., Barlow, P. J., Joshi, P. S., Lo, H. L., \& Chung, Y. K. (2010). Review of rapid testes available for measuring the quality changes in frying oils and comparison with standadr methods. Food Science \& Nutrition, 50(6), 503-514. http://dx.doi. org/10.1080/10408390802544611. PMid:20544441.

Brasil. Ministério da Saúde. Agência Nacional de Vigilância Sanitária. (2005, Setembro 23). Resolução - RDC n² 270, de 22 setembro de 2005. Aprova o "Regulamento Técnico para óleos vegetais, gorduras vegetais e creme vegetal". Diário Oficial [da] República Federativa do Brasil.

Codex Alimentarius. (2013). Codex standard for named vegetable oils (CODEX-STAN 210, Amended 2003-2005). Rome: FAO.

Corrêa, R. H. M. A., Costa, E. G., Taillefer, R. J. F., \& Zorzo, V. (2003). Bahia com pimenta: um estudo comparado da tradução da culinária de dona flor para o francês, o inglês e o espanhol. Terra roxa e outras terras. Revista de Estudos Literários, 3, 52-68.

Corsini, M. S., Jorge, N., Miguel, A. M. R. O., \& Vicente, E. (2008). Perfil de ácidos graxos e avaliação da alteração em óleos de fritura. Quimica Nova, 31(5), 956-961. http://dx.doi.org/10.1590/S010040422008000500003 . 
Curvelo, F. M., Almeida, D. T., Nunes, I. L., \& Feitosa, S. (2011). Qualidade do óleo de palma bruto (Elaeis guineensis): matéria-prima para fritura de acarajés. Revista do Instituto Adolfo Lutz, 70, 641-646.

Dobarganes, M. C., Velasco, J., \& Dieffenbacher, A. (2000). Determination of polar compounds polymerized and oxidized triacylglycerols, and diacylglycerols in oils and fats. Pure and Applied Chemistry, 72(8), 1563-1575. http://dx.doi.org/10.1351/pac200072081563.

Edem, D. O. (2002). Palm oil: Biochemical, physiological, nutritional, hematological, and toxicological aspects: A review. Plant Foods for Human Nutrition, 57(3-4), 319-341. PMid:12602939. http://dx.doi. org/10.1023/A:1021828132707.

Gee, P. T. (2007). Analytical characteristics of crude and refined palm oil and fractions. European Journal of Lipid Science and Technology, 109(4), 373-379. http://dx.doi.org/10.1002/ejlt.200600264.

Instituto Adolfo Lutz - IAL. (2005). Métodos físico-químicos para análise de alimentos (4 ed.). São Paulo: IAL.

Instituto do Patrimônio Histórico e Artístico Nacional - IPHAN. (2005). Dossiê IPHAN 6: Ofício das Baianas do Acarajé. Brasília: IPHAN.

Koushki, M., Nahidi, M., \& Cheraghali, F. (2015). Physico-chemical properties, fatty acid profile and nutrition in palm oil. Journal of Paramedical Sciences, 6(3), 117-134.

Kumar, P. K. P., \& Krishna, A. G. G. (2014). Physico-chemical characteristics and nutraceutical distribution of crude palm oil and its fractions. Grasas y Aceites, 65(2), e018. http://dx.doi.org/10.3989/gya.097413.

Läubli, M. W., \& Bruttel, P. A. (1986). Determination of the oxidative stability of fats and oils: comparison between the active oxygen method (AOCS Cd 12-57) and the rancimat method. Journal of the American Oil Chemists' Society, 63(6), 792-795. http://dx.doi. org/10.1007/BF02541966.

Lody, R. (Org.). (2009). Dendê símbolo e sabor. São Paulo: Editora SENAC.

Matthäus, B. (2007). Use of palm oil for frying in comparison with other high-stability oils. European Journal of Lipid Science and Technology, 109(4), 400-409. http://dx.doi.org/10.1002/ejlt.200600294.

Ndjouenkeu, R., \& Ngassoum, M. (2002). Comparative study of frying behavior of some vegetable oils. Journal of Food Engineering, 52, 121-125. http://dx.doi.org/10.1016/S0260-8774(01)00093-0.

Ng, T. K. W., Low, C. X., Kong, J. P., \& Cho, Y. L. (2012). Use of red palm oil in local snacks can increase intake of provitamin A carotenoids in young aborigines children: a Malaysian experience. Malaysian Journal of Nutrition, 18(3), 393-397. PMid:24568080.

O'Donnell, C. D. (1995). Fats and oils: forces in fried food quality. Prepared Foods, 1, 77-78.

Osawa, C. C., Gonçalves, L. A. G., Gumerato, H. F., \& Mendes, F. M. (2012). Study of the effectiveness of quick tests based on physical properties for the evaluation of used frying oil. Food Control, 26(2), 525-530. http://dx.doi.org/10.1016/j.foodcont.2012.01.008.

Rodriguez-Amaya, D. B. (1996). Assesment of Provitamin A contents of food - the Brazilian experience. Journal of Food Composition and Analysis, 9(3), 196-230. http://dx.doi.org/10.1006/jfca.1996.0028.

Rodriguez-Amaya, D. B., \& Kimura, M. (2004). Harvestplus handbook for carotenoid analysis (HarvestPlus Technical Monograph Series 2). Washington: International Food Policy Research Institute.

Rossi, M., Gianazza, M., Alamprese, C., \& Stanga, F. (2001). The effect of bleaching and physical refining on color and minor components of palm oil. Journal of the American Oil Chemists' Society, 78(10), 1051-1055. http://dx.doi.org/10.1007/s11746-001-0387-8.

Silva, T. O., \& Pereira, P. A. P. (2008). Influence of time, surface-tovolume ratio, and heating process (continuous or intermittent) on the emission rates of selected carbonyl coumpounds during thermal oxidation of palm and soybean oils. Journal of Agricultural and Food Chemistry, 56(9), 3129-3135. PMid:18422332. http://dx.doi. org/10.1021/jf0734525.

Szydłowska-Czerniak, A., Trokowski, K., Karlovits, G., \& Szłyk, E. (2013). Spectroscopic Determination of Metals in Palm Oils from Different Stages of the Technological Process. Journal of Agricultural and Food Chemistry, 61(9), 2276-2283. PMid:23394464. http:// dx.doi.org/10.1021/jf305094s.

Tan, C. P., \& Man, Y. B. C. (2000). Differential scanning calorimetric analysis of edible oils: Comparison of thermal properties and chemical composition. Journal of the American Oil Chemists' Society, 77(2), 143-155. http://dx.doi.org/10.1007/s11746-000-0024-6.

Tarmizi, A. H. A. E., \& Lin, S. W. (2008). Quality assessment of palm products upon prolonged heat treatment. Journal of Oleo Science, 12(12), 639-648. PMid:19001776. http://dx.doi.org/10.5650/jos.57.639.

Trigueiro, I. N. S., \& Penteado, M. V. C. (1993). Características físicas, químicas e estado de oxidação de óleos de dendê brasileiros. Boletim Centro de Pesquisas de Processamento de Alimentos, 11, 103-112.

Visentainer, J. V., \& Franco, M. R. B. (2012). Quantificação de ácidos graxos utilizando padronização interna. Visentainer, J. V., \& Franco, M. R. B. Ácidos graxos em óleos e gorduras: identificação e quantificação (2. ed., p. 9-120). São Paulo: Varela.

Weisshaar, R. (2014). Quality control of used deep-frying oils. European Journal of Lipid Science and Technology, 116(6), 716-722. http:// dx.doi.org/10.1002/ejlt.201300269.

Zeb, A., \& Murkovic, M. (2011). Determination of thermal oxidation and oxidation products of $\beta$-carotene in corn oil triacylglycerols. Food Research International, 50(2), 534-544. http://dx.doi.org/10.1016/j. foodres.2011.02.039. 